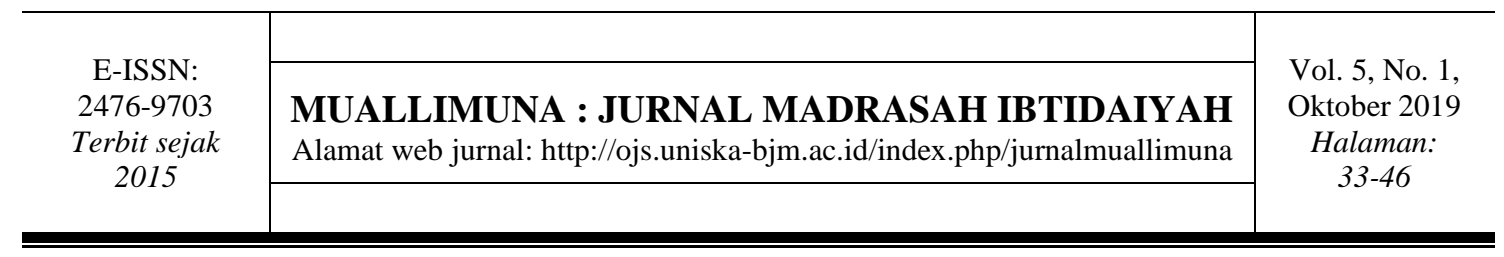

\title{
MODEL PENGEMBANGAN MEDIA PEMBELAJARAN ADAPTIF DI SEKOLAH DASAR
}

\author{
Hamdan Husein Batubara ${ }^{1}$, Dessy Noor Ariani ${ }^{2}$ \\ ${ }^{1}$ Pendidikan Guru Madrasah Ibtidaiyah, Universitas Islam Negeri Walisongo Semarang \\ ${ }^{2}$ Pendidikan Dasar, Universitas Negeri Jakarta \\ ${ }^{1}$ batubara@walisongo.ac.id, ${ }^{2}$ dessynoorarianii@gmail.com
}

\begin{abstract}
Abstrak: Media pembelajaran sebagai salah satu komponen sistem pembelajaran harus sesuai dengan komponen pembelajaran agar fungsinya optimal dalam memfasilitasi kegiatan pembelajaran. Artikel ini bertujuan untuk menjelaskan urgensi, kriteria pemilihan dan prosedur pengembangan media pembelajaran adaptif. Tulisan ini merupakan hasil kajian pustaka dengan cara menelusuri berbagai referensi untuk mendapatkan data yang valid dan dapat dipercaya. Hasil tulisan ini mengungkapkan bahwa urgensi media pembelajaran adaptif di Sekolah Dasar dapat ditinjau dari teori belajar, regulasi pendidikan, dan ajaran agama Islam. Kriteria media pembelajaran adaptif dapat diketahui dari tingkat kesesuaian antara komponen system pembelajaran dengan atribut media pembelajaran, seperti: tujuan pembelajaran, jenis materi, kondisi pengguna, dan lingkungan pembelajaran. Model pengembangan media pembelajaran adaptif dapat mengikuti beberapa model pengembangan sistem pembelajaran. Garis besar prosedurnya adalah: menganalisis kondisi dan kebutuhan komponen pembelajaran, menganalisis dan merumuskan rancangan media pembelajaran, merealisasikan rancangan media pembelajaran, dan melakukan evaluasi berkelanjutan dengan melibatkan pakar dan target pengguna untuk memberikan penilaian terhadap kualitas media pembelajaran.
\end{abstract}

\section{Kata Kunci: model pengembangan, media pembelajaran, adaptif, sekolah dasar \\ MODEL OF ADAPTIVE INSTRUCTIONAL MEDIA DEVELOPMENT AT ELEMENTARY SCHOOL}

Abstract: Instructional media as one component of the instructional system has to adaptive with the learning component so that its function is optimal in facilitating learning activities. This article aims to explain the urgency, selection criteria, and procedures for developing adaptive instructional media. This article uses the literature review method by tracing various reference sources critically to get complete and reliable data. The results of this paper explain that the urgency of adaptive instructional media in elementary schools can be viewed from the learning theory, educational regulation, and Islamic text. The criteria for adaptive instructional media can be known from the level of appropriateness between learning system components and instructional media attributes, such as instructional objectives, material types, user conditions, and learning environment. Models of adaptive learning media development can follow existing learning development models. The procedure outline is: analyzing the conditions and needs of the learning component, analyzing and formulating learning media designs, realizing 
34

learning media designs, and conducting ongoing evaluations by involving experts and target users to provide an assessment of the quality of instructional media.

\section{Keywords: development model, instructional media, adaptive, elementary school}

\section{PENDAHULUAN}

Media adalah segala sesuatu yang mengantar dan menyajikan informasi dari sumber kepada penerima pesan, baik ia berperan sebagai jalur komunikasi, alat bantu komunikasi, sarana penyaji informasi, atau metode yang menghubungkan seseorang dengan informasi (Muhammad Yaumi, 2018, p. 5; Pusat Bahasa, 2009, p. 378; Suryani, Setiawan, \& Putria, 2018, p. 2). Dari pengertian media tersebut, beberapa pakar telah mengungkapkan definisi media pembelajaran dengan pengertian yang beragam. Adapaun garis besar pengertian media pembelajaran adalah segala bentuk benda (misalnya: instrumen, sarana, saluran komunikasi) dan peristiwa yang dapat dimanfaatkan oleh peserta didik dan pendidik untuk mendukung dan memfasilitasi kegiatan pembelajaran sehingga hasil belajar dapat tercapai dengan efektif dan efisien (Haryadi et al., 2019, p. 1; Mashuri, 2019, p. 4; Moreira, Pereira, \& Gusmão, 2018, p. 105; Widodo, 2018, p. 159). Format media tersebut dapat berupa teks, audio, visual, video, benda hasil rekayasa, dan manusia (Smaldino, Lowther, \& Russell, 2012, p. 7).

Dari pengertian media pembelajaran di atas dapat disimpulkan bahwa media pembelajaran merupakan salah satu komponen pembelajaran yang berkaitan erat dengan komponen pembelajaran lainnya, seperti: metode, materi, tujuan, dan peserta didik. Adapun tujuan dari media pembelajaran adalah untuk memfasilitasi kegiatan pembelajaran (Smaldino et al., 2012, p. 7). Dengan demikian, media pembelajaran memiliki kedudukan yang sangat penting untuk menciptakan proses pembelajaran yang kreatif dan efektif dalam mencapai tujuan pembelajaran.

Di antara manfaat yang diperoleh oleh peserta didik dari penggunaan media pembelajaran adalah: 1) meningkatkan rasa ingin tahu dan motivasi belajarnya, 2) membantunya dalam memahami konsep yang abstrak dan rumit, 3) menarik perhatian, 4) merangsang dan meningkatkan kemampuan pikirnya, 5) membuat tempat dan waktu belajarnya menjadi lebih fleksibel, dan 6) mengakomodasi berbagai cara dan gaya belajarnya (Rusman, Kurniawan, \& Riyana, 2012; Saputra \& Kuswanto, 2019; Suryani et al., 2018).

Disamping itu, media pembelajaran juga bermanfaat bagi pendidik untuk: 1) meningkatkan rasa percaya dirinya, membantunya dalam menarik perhatian dan meningkatkan motivasi belajar peserta didiknya, 2) membantunya dalam memvisualisasikan, menyederhanakan, dan mengurutkan penyajian materi, 3) membantunya dalam menerapkan metode pembelajaran yang berpusat pada peserta didik, dan mengatasi masalah keterbatasan waktu belajar di kelas (Rusman et al., 2012; Suryani et al., 2018).

Berdasarkan beberapa manfaat yang diperoleh dari penggunaan media pembelajaran, maka dapat disimpulkan bahwa media pembelajaran adalah salah satu komponen pembelajaran yang harus dipilih oleh guru secara selektif dan serius agar fungsi dan manfaatnya dapat diperoleh secara maksimal (John, Barasa, \& Omulando, 2017; Smaldino et al., 2012).

Problematika ataupun masalah penggunaan media pembelajaran di sekolah dasar cukup beragam, di antara adalah: 1) guru tidak memfasilitasi peserta didik dengan sumber belajar yang beragam, 2) guru belum menguasai konsep materi secara 
mendalam sehingga ia masih kesulitan dalam memanfaatkan lingkungan sekolah sebagai media pembelajaran, 3) guru masih kesulitan dalam mengakses dan memilih media pembelajaran yang sesuai dengan kondisi pembelajarannya, 4) kondisi infrastruktur di beberapa sekolah atau daerah masih menjadi kendala dalam penerapan media pembelajaran berbasis teknologi, dan 5) kompetensi teknologi guru masih belum memadai untuk mengembangkan media berbasis komputer secara mandiri (Batubara, 2017; Hadi, 2017; Kurniawan, Wahyuningsih, \& Pangadongan, 2019).

Berdasarkan uraian masalah tersebut, maka penting kajian tentang urgensi media pembelajaran adaptif, kriteria-kriteria media pembelajaran adaptif, dan prosedur memilih media pembelajaran adaptif. Hasil kajian ini diharapkan dapat mendorong para pendidik untuk menggunakan media pembelajaran yang adaptif dengan kondisi peserta didiknya, komponen pembelajarannya, dan lingkungan kerjanya.

\section{METODE}

Artikel ini adalah hasil dari studi pustaka (library research). Studi pustaka bertujuan untuk mengumpulkan dan menganalisis data atau informasi ilmiah, seperti: jurnal, laporan hasil penelitian, majalah ilmiah, surat kabar, buku yang relevan, hasilhasil seminar, artikel ilmiah yang belum di publikasikan, dan data ilmiah lain yang berkaitan dengan media pembelajaran adaptif (Sukardi, 2003).

Metode pengumpulan data tulisan ini dilakukan dengan metode eksploratif, yakni menganalisis berbagai macam karya tulis ilmiah yang berkaitan dengan urgensi media pembelajaran adaptif, kriteria media pembelajaran adaptif, dan prosedur memilih media pembelajaran adaptif.

Teknik analisis data yang diterapkan pada artikel ini adalah analisis isi (content analysis), yaitu mengkaji secara mendalam suatu informasi tertulis untuk menemukan informasi yang lengkap melalui: perumusan forkus kajian, melakukan sampling terhadap sumber-sumber data yang telah dipilih, pengumpulan dan penafsiran data yang diperoleh .

\section{HASIL DAN PEMBAHASAN \\ Urgensi Media Pembelajaran Adaptif}

Urgensi media pembelajaran adaptif dapat dianalisa dari berbagai aspek yang melandasi kegiatan pembelajaran, seperti: teori belajar, regulasi pendidikan, dan ajaran Islam. Adapun urgensi media pembelajaran berdasarkan tiga landasan tersebut adalah sebagai berikut.

\section{Media dalam Perspektif Teori Belajar}

Kegiatan pembelajaran yang sesuai akan dapat dipastikan setelah memahami cara belajar peserta didik. Cara belajar peserta didik telah banyak dikaji oleh pakar psikologi sehingga telah melahirkan berbagai jenis teori belajar. Teori belajar yang diplopori oleh pakar behaviorisme antara lain adalah: 1) belajar melalui coba-coba, latihan, hukum akibat, dan hukum kesiapan, 2) kegiatan belajar harus direncanakan berdasarkan tujuan yang jelas, dan 3) aktivitas belajar dapat dikoordinasikan dengan hadiah dan hukuman (Jamaris, 2015, p. 120; Schunk, 2012).

Implikasi dari teori belajar behavioristik terhadap penggunaan media pembelajaran adalah sebagai berikut.

a. Pemilihan media pembelajaran harus memperhatikan kesesuaiannya dengan komponen sistem pembelajaran, seperti tujuan pembelajaran, materi pelajaran, metode pembelajaran, kesiapan dan kebutuhan peserta didik. 
b. Penyajian materi pembelajaran dapat diprogram menggunakan bantuan media pembelajaran sehingga dapat tersajikan secara sistematis, fleksibel, dan melibatkan beragam media.

c. Metode pemahaman konsep kepada peserta didik menggunakan media pembelajaran dapat menggunakan pendekatan simulasi, latihan, permainan, dan sesuatu yang dapat memperkuat respon/minat belajar peserta didik.

d. Hasil dari penggunaan media pembelajaran harus diukur dan dievaluasi.

Teori belajar yang diplopori oleh pakar kontruktivisme adalah: 1) teori perkembangan kognitif Piaget (Sani, 2019, pp. 13-14), 2) teori tahapan kognitif Bruner (Jamaris, 2015, p. 133), 3) teori pembelajaran bermakna Ausubel (Jamaris, 2015, p. 139), 4) teori pemrosesan informasi Gagne (Sani, 2019, p. 16), 5) teori kontruktivisme sosial Vygotsky (Rahmat, 2018, p. 661), dan 6) teori kognitif sosial Bandura (Schunk, 2012).

Implikasi teori kontruktivisme terhadap penggunaan media pembelajaran adalah sebagai berikut.

a. Pendidik harus menata sistematika penyajian materi pelajaran dari yang sederhana/ mudah ke materi yang sulit/ rumit

b. Pendidik harus memfasilitasi peserta didik dengan media pembelajaran yang dapat memberikan contoh, model, atau tutorial yang praktis untuk diamati dan ditiru oleh peserta didik,

c. Pendidik harus memastikan lingkungan belajar peserta didik dapat meningkatkan perhatian, motivasi, dan kemandirian belajar peserta didik,

d. Pendidik harus menyesuaikan rangkaian tindakan dalam pembelajaran dengan harapan agar dapat meningkatkan keyakinan peserta didik terhadap kemampuanya (efikasi-diri).

Teori belajar yang dipropori oleh humanistik adalah: 1) teori hirarki kebutuhan Maslow, dan 2) teori self Roger. Kedua pakar humanisme ini menekankan kegiatan belajar pada masalah kepribadian manusia. Misalnya, tingkat kebutuhan diri manusia (kebutuhan fisiologis, kebutuhan rasa aman, kebutuhan untuk mencintai dan dicintai, kebutuhan untuk dihargai, dan kebutuhan aktualisasi diri), dan persepsi manusia tentang dirinya sebagai manusia (Jamaris, 2015, pp. 161-164).

Implikasi dari teori humanisme terhadap penggunaan media pembelajaran adalah sebagai berikut:

a. Penggunaan media pembelajaran harus memperhatikan peran diri peserta didik, kondisi kemampuannya, dan aktualisasi dirinya

b. Penggunaan media pembelajaran dapat digunakan untuk membangkitkan kesadaran peserta didik untuk belajar mandiri atau melakukan aktivitas berdasarkan kemauan sendiri

c. Kehadiran media pembelajaran penting untuk memfasilitasi kegiatan pembelajaran yang berpusat pada peserta didik.

\section{Media dalam Perspektif Regulasi Pendidikan}

Penggunaan media pembelajaran sebagai salah satu komponen pembelajaran telah tercantum di berbagai peaturan perundangan dan peraturan pemerintah, yaitu sebagai berikut.

a. Undang-undang Republik Indonesia nomor 20 tahun 2003 tentang Sistem Pendidikan Nasional menyebutkan bahwa pembelajaran adalah proses interaksi peserta didik dengan pendidik dan sumber belajar pada suatu lingkungan belajar 
(Pemerintah Republik Indonesia, 2003, p. 2). Berdasarkan pernyataan ini, sumber belajar yang terkadang juga berupa media pembelajaran dinyatakan sebagai salah satu komponen pembelajaran yang diperlukan untuk mendukung kegiatan pembelajaran.

b. Peraturan Pemerintah Republik Indonesia Nomor 19 Tahun 2005 Tentang Standar Nasional Pendidikan menyatakan bahwa setiap satuan pendidikan wajib memiliki sarana yang meliputi perabot, peralatan pendidikan, media pendidikan, buku dan sumber belajar lainnya, bahan habis pakai, serta perlengkapan lain yang diperlukan untuk menunjang proses pembelajaran yang teratur dan berkelanjutan (Pemerintah Republik Indonesia, 2005, p. 31).

c. Peraturan Menteri Pendidikan Nasional Republik Indonesia Nomor 24 Tahun 2007 Tentang Standar Sarana dan Prasarana Untuk Sekolah Dasar/Madrasah Ibtidaiyah (SD/MI), Sekolah Menengah Pertama/Madrasah Tsanawiyah (SMP/MTs), dan Sekolah Menengah Atas/Madrasah Aliyah (SMA/MA) menetapkan media pembelajaran berupa papan tulis sebagai salah satu sarana ruang kelas/ Laboratorium dan satu set komputer (CPU, monitor minimum 15 inci, printer), TV, radio, dan pemutar VCD/DVD) sebagai salah satu sarana perpustakaan (Menteri Pendidikan Nasional Republik Indonesia, 2007, p. 41).

d. Salinan Peraturan Menteri Pendidikan Nasional nomor 16 tahun 2007 tentang standar kompetensi dan kualifikasi guru menyebutkan bahwa kemampuan menggunakan media dan sumber belajar adalah salah satu indikator kompetensi pedagogik, yaitu di bidang kemampuan menyelenggarakan pembelajaran yang mendidik (Pemerintah Republik Indonesia, 2007, p. 19).

e. Peraturan Menteri Pendidikan dan Kebudayaan Republik Indonesia Nomor 22 Tahun 2016 tentang Standar Proses Pendidikan Dasar dan Menengah memasukkan proses penyiapan media dan sumber belajar ke dalam bagian perencanaan pembelajaran (Menteri Pendidikan dan Kebudayaan RI., 2016, pp. 5-7, dan 11).

\section{Media dalam Perspektif Ajaran Agama Islam}

Konsep media pembelajaran menurut Agama Islam dapat dintinjau dari penjelasan ayat suci Al Quran dan Hadis tentang alat yang digunakan untuk menyampaikan pesan-pesan ajaran agama Islam. Adapun di antara ayat dan hadis yang menunjukkan beberapa kategori media pembelajaran adalah sebagai berikut.

a. Media Audio atau Bunyi

Media audio adalah media yang menyampaikan pesan dengan bunyi. Bunyi tersebut dapat berupa suara manusia, suara efek benda, musik, dan lain sebagainya. Penggunaan audio sebagai media penyampai pesan dapat diketahui dari beberapa ayat Al Quran yang menggunakan kata wahai, ceritakan, bacalah, dan jelaskan di dalam (Wahidin \& Syaefuddin, 2018, p. 53). Adapun contoh ayat Al Quran yang menggunakan kata kunci ceritakanlah adalah: 1) surah Al A'rof [7] ayat: 176 menunjukkan bahwa media lisan dapat diterapkan melalui cerita sehingga dapat menarik perhatian dan merangsang pikiran (Munir, 2008, pp. 141-180), 2) surah AtTaubah [9] ayat 11 menunjukkan bahwa media suara tepat untuk menjelaskan pengetahuan faktual, dan 3) surah Al Baqarah [2] ayat 261 menunjukkan bahwa media audio dapat disampaikan melalui perumpamaan sehingga mudah dimengerti 
pendengarnya. Dalam perkembangan selanjutnya, media audio telah didukung oleh berbagai teknologi, seperti: pengeras suara, radio, dan audio streaming.

b. Media Teks atau Tulisan

Teks adalah media yang menggunakan huruf dan kata-kata sebagai media penyampaian pesan. Teks dapat menyampaikan pesan secara langsung sehingga ia cukup efektif digunakan untuk menyampaikan ide atau memberikan panduan kepada pengguna. Secara umum, teks terbagi menjadi empat macam, yaitu: teks cetak, teks hasil scan, teks elektronik, dan hyperteks (Suyanto, 2005, p. 256).

Adapun ayat Al Quran yang menunjukkan penggunaan teks sebagai media pembelajaran adalah: 1) surah Al-Alaq [96] ayat 4 menunjukkan bahwa ilmu pengetahuan dapat ditransfer menggunakan media tulisan (Qalam) (Nata, 2009, p. 49), 2) surah An-Naml [27] ayat 20, 28- 32 telah menceritakan bahwa bahwa Nabi Sulaiman pernah melakukan korrespondensi atau mengirimkan surat kepada Ratu Bilqis dengan menggunakan burung Hudhud sebagai media pengantarnya.

Disamping itu, terdapat juga beberapa hadis yang menunjukkan penggunaan media tulisan, yaitu: 1) hadis yang diriwayatkan oleh Imam Bukhori pada nomor hadis 2.610 menunjukkan bahwa orang tua atau pendidik dapat menggunakan media tulisan saat mengajarkan do'a-do'a kepada anak-anaknya (Khon, 2014, p. 355), 2) beberapa hadi menceritakan bahwa Rasulullah SAW. pernah mengirimkan surat kepada kaisar Romawi dan penguasa Persia (Tim Lajnah Pentashihan Mushaf Al-Qur'an, 2019, p. 65).

c. Media Visual atau Gambar

Media visual adalah media yang dapat ditangkap melalui indera penglihatan tanpa adanya suara dari alat tersebut (Wahidin \& Syaefuddin, 2018, p. 55). Media visual mencakup bahan yang berwujud garis, warna, bentuk, dan ruang yang didesain untuk menyampaikan suatu pesan (Muhammad Yaumi, 2018, p. 132). Contoh media visual antara lain adalah diagram, gambar, benda nyata, dan bahan lain yang dapat di lihat oleh mata.

Adapun ayat Al Quran yang menunjukkan penggunaan media visual sebagai sarana dan media belajar adalah: surah Al-Dhariyat [51] ayat 20-21 dan surah Al Ghashiyah ayat 17-20 menunjukkan bahwa bumi dan diri manusia adalah sumber dan media belajar untuk mengetahui kebesaran Allah SWT (Yusuf, 2013, p. 54), 2) surah Faatir [35] ayat 27 menunjukkan bahwa Allah SWT. telah mengajak manusia untuk memikirkan dan mempelajari berbagai peristiwa yang terjadi di alam semesta.

Adapun contoh hadis Rasululah shollollohu 'alaihi wasallam yang menunjukkan penggunaan media visual adalah hadis yang diriwayatkan oleh Imam Bukhori pada nomor Hadis 5938/ Fatkhul Bari: 6417. Hadis tersebut telah menunjukkan bahwa Nabi Muhammad SAW. Pernah menggunakan media sketsa gambar untuk menjelaskan perihal perjalanan hidup manusia, dimana ajal dan cobaan selalu mengintai manusia dan angan-angan manusia telah melampaui ajalnya (batas usianya).

Adapun petunjuk Al Quran tentang penggunaan media pembelajaran adaptif adalah sebagai berikut.

a. Materi media pembelajaran

Materi media pembelajaran sebagai pesan yang disampaikan harus memenuhi unsur kebenaran dan kesesuaian dengan kondisi penerima informasi. Hal tersebut sesuai dengan firman Allah SWT. di dalam surah Al Imran ayat 60 dan hadis riwayat Imam Bukhori nomor 5671/ Fatkhul Bari: 6136). Oleh karena itu, setiap orang harus memastikan kebenaran dan kesesuaian materi media terlebih dahulu sebelum menggunakannya (Tim Lajnah Pentashihan Mushaf Al-Qur'an, 2019, p. 67). 
b. Fitur media pembelajaran

Media pembelajaran yang baik adalah media yang memiliki fitur untuk menyajikan materi pelajaran dengan beragam pendekatan sehingga pendidik atau guru dapat memilih pendekatan yang paling baik atau sesuai. Hal tersebut dapat dipahami dari firman Allah SWT. pada surah An Nahl [16] ayat 125.

c. Fungsi media pembelajaran

Surah Ar Ra'd [13] ayat 3 mengungkapkan bahwa satu fungsi media pembelajaran adalah untuk merangsang pikiran sehingga menimbulkan kesadaran terhadap tanda-tanda kebesaran Allah SWT.

Berdasarkan uraian ayat dan hadis tersebut dapat disimpulkan bahwa Al Quran dan Hadis telah menunjukkan beberapa jenis media pembelajaran dalam proses pembelajaran. Disamping itu, ajaran Islam juga dapat dijadikan panduan dalam menggunakan media pembelajaran.

\section{Kriteria Pemilihan Media Pembelajaran Adaptif}

Media pembelajaran adalah salah satu komponen sistem pembelajaran. Sebagai komponen, media pembelajaran sudah seharusnya bersifat adaptif, yaitu menyesuaikan dirinya dengan proses pembelajaran secara menyeluruh. Oleh karena itu, seorang pendidik tidak boleh sembarangan dalam memilih media pembelajaran. Ia harus tunduk pada kriteria-kriteria yang dapat dijadikan sebagai pedoman dalam memilih media pembelajaran yang adaptif.

Menurut Rifai, beberapa kriteria yang harus dipertimbangkan dalam memilih media pembelajaran adalah: 1) tujuan penggunaan media, 2) sasaran penggunaan media, 3) karakteristik media, 4) alokasi waktu yang dimiliki, 5) biaya yang diperlukan, dan 6) ketersedian media (Rifai, 2017, p. 134). Dari keenam kriteria tersebut dapat dianalisa bahwa media pembelajaran adaptif adalah media pembelajaran yang sesuai dengan tujuan pembelajaran, kebutuhan dan kondisi pengguna, dan kondisi lingkungan secara menyeluruh (Prastowo, 2018, p. 30; Wicaksono, Irmade, \& Jumanto, 2017, p. 117).

Musfiqon (2012) dalam Suryani menambahkan empat kriteria yang harus dipertimbangkan dalam pemilihan media pembelajaran, yaitu: 1) kesesuaian jenis media dengan materi pelajaran, 2) dukungan kondisi lingkungan belajar, 3) tingkat keamanan pengguna, dan 4) dan kualitas media pembelajaran itu sendiri (Suryani et al., 2018, pp. 63-64).

Selain kriteria tersebut, Rudi Susilana (dalam Abdullah) telah mengusulkan enam kriteria yang harus dijadikan sebagai pedoman pemilihan media, yaitu: ACTION (access, cost, technology, interactivity, organization, dan novelity). Access berarti kemudahan akses atau ketersediaan media, Cost berarti biaya yang diperlukan dibandingkan dengan manfaatnya, Technology berarti ketersediaan dan kemudahan penggunaan teknologi pendukung media, Interactivity berarti kemampuan media dalam menciptakan komunikasi dua arah, Organization berarti dukungan organisasi pendidikan, dan Novely berarti tingkat kebaruan dari media yang dipilih (Abdullah, 2016, pp. 38-39).

Megawati mengemukakan empat syarat yang harus dipertimbangkan dalam memilih media pembelajaran, yaitu: 1) rasional, yaitu masuk akal atau mampu dipikirkan penngunanya, 2) ilmiah, yaitu sesuai dengan kaidah-kaidah ilmu pengetahuan, 3) ekonomis, yaitu sesuai dengan kemampuan pembiayaan sehingga lebih hemat dan efisien, dan 4) praktis, yaitu dapat segera digunakan oleh penggunanya (Megawati, 2017, pp. 109-110). 
Dari beberapa kriteria di atas, penulis menyimpulkan bahwa tidak ada satu jenis media pembelajaran yang unggul untuk semua kondisi pembelajaran (Rifai, 2017, p. 134). Oleh karena itu, pendidik harus menyesuaikan jenis media pembelajaran dengan kondisi komponen pembelajaran lainnya. Beberapa komponen pembelajaran yang perlu diperhatikan sebelum memilih media pembelajaran antara lain adalah:

a. Tujuan pembelajaran

Tujuan pembelajaran adalah sejumlah kompetensi yang terukur dan diharapkan muncul pada diri peserta didik setelah mengikuti kegiatan pembelajaran. Tujuan pembelajaran menjadi salah satu landasan pokok bagi pendidik untuk memilih materi dan media pembelajaran.

b. Jenis materi

Jenis materi pelajaran dapat ditinjau dari jenis pengetahuan yang terkandung di dalam materi. Misalnya, pengetahuan fakta (seperti: terminologi, lokasi, dan fakta) disajikan dengan media benda nyata, manipulatif, media teks, dan gambar diam, sementara pengetahuan konsep (kategori, klasifikasi, prinsip, teori, model, dan struktur) disajikan dengan peta konsep, poster, dan benda manipulatif, sedangkan media pengetahuan prosedural (pengetahuan tentang cara melakukan sesuatu) disajikan dengan media interaktif dan benda nyata, dan pengetahuan metakognitif (kognisi dan kesadaran diri sendiri) disajikan dengan media video (Anderson, Krathwohl, \& Anderson, 2010; Sahidin, Budiarto, \& Fuad, 2019).

c. Kondisi pengguna

Kondisi pengguna adalah meliputi: 1) tingkat perkembangan kognitifnya, 2) tingkat kompetensinya, 3) infrastruktur yang dimilikinya, dan 4) kepercayaan yang di anutnya. Misalnya, kognitif anak usia Sekolah Dasar membutuhkan bantuan media visual untuk memahami konsep yang abstrak, penggunaan media video mengharuskan penggunanya mampu menggunakan alat pemutar video, dan jenis media pembelajaran yang digunakan harus sesuai dengan nilai-nilai kepercayaan, kemanusiaan, dan estetika.

d. Kondisi lingkungan belajar

Kondisi lingkungan belajar adalah kondisi dimana kegiatan pembelajaran berlangsung. Adapun beberapa hal yang harus diperhatikan pada lingkungan belajar adalah: 1) sarana pendukung yang dimiliki oleh lingkungan belajar, 2) ketersediaan waktu belajar, 3) ketersediaan bantuan teknis, dan 4) kondisi cuaca pada saat proses pembelajaran berlangsung.

Adapun beberapa atribut media pembelajaran yang perlu diperhatikan aspek kesesuaiannya dengan kondisi faktual pembelajaran dan potensinya dalam mewujudkan pembelajaran yang menarik adalah sebagai berikut.

a. Konten Media Pembelajaran

Konten media pembelajaran dapat dilihat dari tingkat kesesuaiannya dengan kurikulum dan kebutuhan pengguna. Misalnya, materi media pembelajaran menggunakan bahasa yang baik, sistematis, estetikanya menarik, dan memiliki kualitas audio dan visual yang baik.

b. Fitur

Adapun fitur media pembelajaran dapat dilihat dari kemampuannya dalam melayani berbagai kegiatan pembelajaran. Misalnya: 1) media pembelajaran memungkinkan untuk digunakan oleh individu, kelompok kecil, dan kelompok besar, 2) media pembelajaran dapat digunakan untuk memfasilitasi kegiatan 
penyajian materi, pengelolaan tugas, dan penilaian, dan 3) media pembelajaran dapat melakukan komunikasi interaktif (dua arah) dengan penggunanya.

c. Harga

Harga yang dimaksud di sini meliputi biaya pembelian produk, teknologi pendukungnya, dan biaya perawatannya. Harga dari sebuah barang antara lain dipengaruhi oleh kualitas bahan, kecanggihan fiturnya, kuantitas produksinya, dan proses distribusinya.

d. Ketersediaan

Ketersediaan adalah berkaitan dengan kesesuaian jumlah produk yang tersedia dengan kebutuhan, ketersediaan alat transportasi untuk menghadirkan media tersebut, dan kemampuan infrastruktur sekolah atau para penggunanya untuk menggunakannya di sekolah dan di luar sekolah.

e. Kepraktisan

Kepraktisan media pembelajaran dapat dilihat dari aspek: 1) tingkat kecepatan pengguna dalam memahami cara menggunakannya, 2) tingkat fleksibilitas media pembelajaran dengan berbagai tempat dan waktu, dan 3) kemudahan dalam perawatan.

f. Keawetan

Keawetan media pembelajaran berkaitan dengan daya tahan media pembelajaran saat digunakan dalam jangka waktu yang lama, berulangkali, dan di berbagai tempat yang berbeda.

g. Tingkat kebaruan

Media pembelajaran baru biasanya menawarkan pengalaman yang berbeda dan lebih menarik di bandingkan dengan pengalaman yang diberikan oleh media pembelajaran sebelumnya. Oleh karena itu, pendidik dan peserta didik penting untuk mengenali dan memanfaatkan media pembelajaran baru agar proses pembelajaran lebih menarik dan tidak ketinggalan zaman.

\section{Prosedur Pemilihan Media Pembelajaran Adaptif}

Media pembelajaran sebagai salah satu sistem pembelajaran berkaitan langsung dengan komponen pembelajaran lainnya. Oleh karena itu, prosedur pengembangan media pembelajaran adaptif dapat diadaptasi dari berbagai model pengembangan desain pembelajaran. Adapun beberapa model yang dijadikan sebagai pedoman dalam pengembangan media pembelajaran adaptif adalah sebagai berikut.

\section{Model $4 \mathrm{D}$}

Thiagarajanan (dalam Ditta, Irawati, \& Susilowati, 2019, p. 80) menjelaskan bahwa langkah-langkah model $4 \mathrm{D}$ terdiri dari 4 kegiatan, yaitu: 1) define, 2) design), 3) develop, dan 4) disseminate. Prosedur pengembangan media pembelajaran berdasarkan model 4 D adalah: 1) menganalisis kebutuhan tujuan pembelajaran, kondisi lingkungan belajar, dan kebutuhan target pengguna media, 2) merumuskan rancangan media pembelajaran yang sesuai dengan rekomendasi hasil analisis, 3) merealisasi rancangan media pembelajaran adaptif melalui kegiatan pemanfaatan dan pengembangan media, 4) menerapkan dan mengkomunikasikan hasil penggunaan media pembelajaran adaptif.

\section{Model ADDIE}

Robert Maribe Branch mengemukakan model ADDIE (akronim dari analyze, design, development, implementation, dan evaluation) sebagai pendekatan atau kerangka kerja yang efektif dan fleksibel dalam pemilihan media pembelajaran adaptif (Branch, 2009). Konsep ADDIE digambarkan sebagai berikut. 


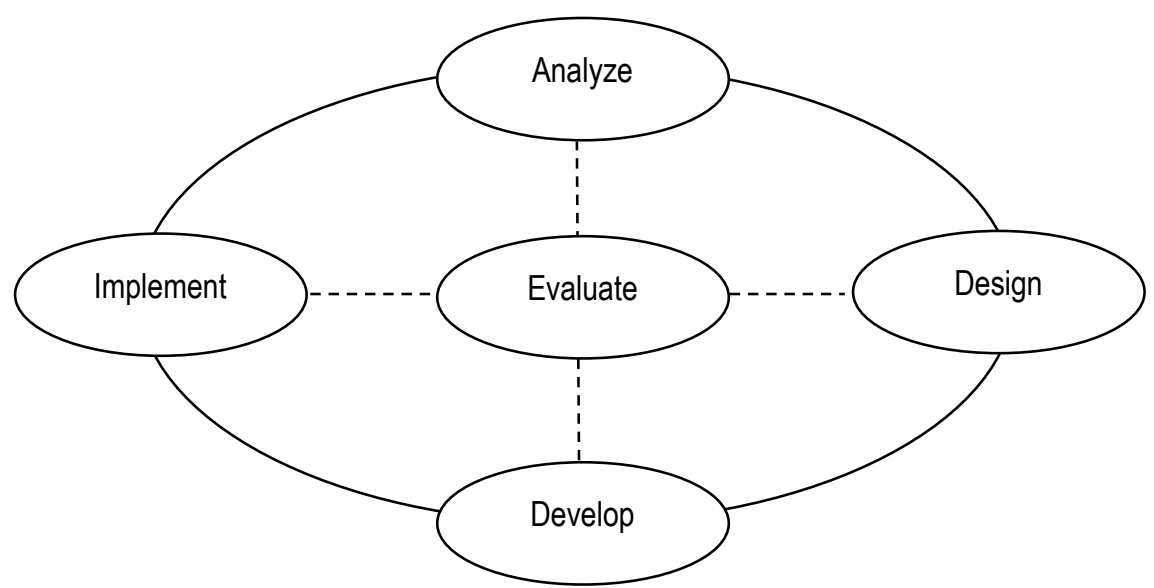

Gambar 1. Konsep ADDIE (Branch, 2009)

Prosedur pengembangan media pembelajaran berdasarkan model ADDIE Branch (Branch, 2009) adalah: 1) menganalisis kebutuhan kurikulum baku, kondisi lingkungan belajar, dan target pengguna media, 2) merumuskan rancangan media pembelajaran yang sesuai dengan hasil analisis, 3) merealisasi rancangan media pembelajaran dengan melibatkan tim pakar atau teman sejawat untuk memberikan masukan, 4) menggunakan media pembelajaran adaptif dan meminta umpan balik dari pengguna tentang kualitas media pembelajaran tersebut, dan 5) mengevaluasi dan merevisi media pembelajaran.

\section{Model Dick \& Carey}

Dick, Carey \& Carey (Dick, Carey, \& Carey, 2015) mengemukakan model pendekatan sistem sebagai model pengembangan system pembelajaran, termasuk pengembangan media sebagai salah satu komponen pembelajaran. Model pendekatan sistem Dick and Carey telah diadopsi oleh Gall, Borg \& Gall dan digunakan oleh banyak peneliti sebagai model penelitian dan pengembangan, khususnya di bidang desain pembelajaran dan produk-produk pendidikan (Gall, Gall, \& Borg, 2003). Prosedur pengembangan media pembelajaran menurut model Dick \& Carey adalah sebagai berikut.

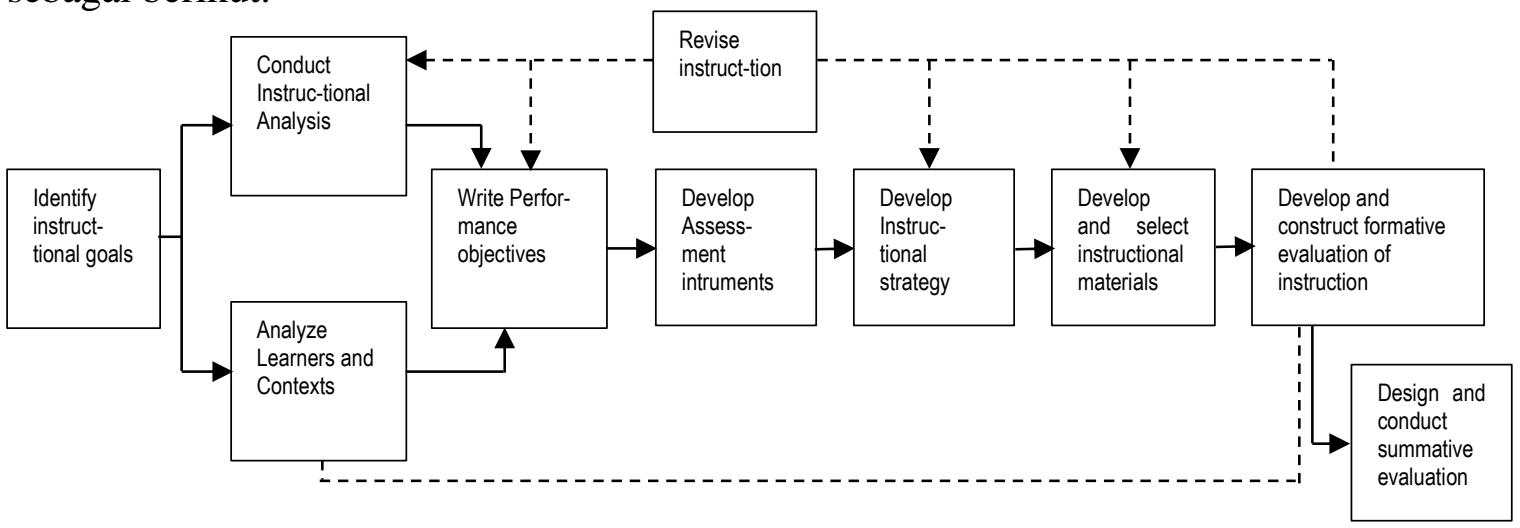

Gambar 2. Model pengembangan sistem pembelajaran Dick \& Carey

Borg dan Gall menjelaskan bahwa prosedur pengembangan model pendekatan sistem Dick \& Carey harus dilakukan secara sistematis dengan 10 tahapan, yaitu: 1) mengidentifikasi tujuan akhir yang ingin dicapai, 2) menelaah kurikulum yang berlaku, 
seperti: bentuk penugasan dan desain pembelajaran yang tepat, 3) menganalisis kondisi faktual pengguna, 4) merumuskan tujuan-tujuan yang terukur berdasarkan tujuan pembelajaran dan hasil analisis kebutuhan, 5) mengembangkan instrument penilaian yang dapat mengukur hasil pembelajaran, 6) mengembangkan strategi pembelajaran yang dapat membantu peserta didik dalam mencapai tujuan pembelajaran, 7) memilih materi dan media pembelajaran yang adaptif, 8) mengembangkan materi dan media pembelajaran melalui kegiatan uji coba, 9) merevisi media pembelajaran berdasarkan hasil evaluasi formatif, dan 10) merancang dan melaksanakan evaluasi sumatif untuk melihat kesesuaian media pembelajaran dengan komponen pembelajaran (Gall et al., 2003).

Berdasarkan beberapa model di atas, maka dapat disimpulkan bahwa garis besar dari prosedur pengembangan media pembelajaran terdiri dari tiga langkah utama, yaitu: 1) perencanaan, yaitu menganalisis kondisi dan kebutuhan komponen pembelajaran, seperti: kurikulum yang berlaku, sarana dan lingkungan belajar, kompetensi dan karakteristik pengguna media, 2) perancangan, yaitu menganalisis dan merumuskan rancangan media pembelajaran yang dibutuhkan, seperti: menganalisis jenis media adaptif, merumuskan storyboard media, mempersiapkan bahan dan instrument penilaian, 3) pengembangan, yaitu kegiatan merealisasikan rancangan media pembelajaran melalui kegiatan pengembangan atau pemrograman, dan 4) evaluasi, yaitu melakukan evaluasi berkelanjutan dengan melibatkan pakar dan target pengguna untuk memberikan penilaian terhadap kualitas media pembelajaran.

\section{PENUTUP}

Berdasarkan pembahasan di atas, penulis mengambil beberapa kesimpulan sebagai berikut.

1. Penggunaan media pembelajaran adaptif sebagai sarana pembelajaran telah didukung oleh teor-teori belajar, regulasi pendidikan, dan ajaran agama Islam.

2. Media pembelajaran adaptif adalah media yang atributnya memenuhi kebutuhan dan kondisi komponen pembelajaran, seperti: tujuan pembelajaran, jenis materi, kondisi pengguna, dan lingkungan pembelajaran.

3. Model pengembangan media pembelajaran adaptif dapat mengikuti beberapa model pengembangan sistem pembelajaran, seperti model 4D, model ADDIE, dan model Dick \& Carey. Garis besar prosedur pengembangan media adalah: menganalisis kondisi dan kebutuhan komponen pembelajaran, menganalisis dan merumuskan rancangan media pembelajaran, merealisasikan rancangan media pembelajaran, dan melakukan evaluasi berkelanjutan dengan meminta penilaian pakar dan target pengguna. 


\section{DAFTAR PUSTAKA}

Abdullah, R. (2016). Pembelajaran Dalam Perspektif Kreativitas Guru Dalam Pemanfaatan Media Pembelajaran. Lantanida Journal, 4(1), 35.

Anderson, L. W., Krathwohl, D. R., \& Anderson, L. W. (2010). Kerangka landasan untuk pembelajaran, pengajaran, dan asesmen. Yogyakarta: Pustaka Pelajar, 300, 41.

Batubara, H. H. (2017). Pengembangan Media Pembelajaran Matematika berbasis Android untuk Siswa SD/MI. Muallimuna: Jurnal Madrasah Ibtidaiyah, 3(1), 1227.

Branch, R. M. (2009). Instructional Design: The ADDIE Approach (Vol. 722). New York: Springer Science \& Business Media.

Dick, W., Carey, L., \& Carey, J. O. (2015). The Systematic Design of Instruction (E. Edition, ed.). New York: Pearson.

Ditta, Z. M., Irawati, M. H., \& Susilowati, S. (2019). Developing Manual Book of Household Wet Waste Composting Experiment by Using Decayed Pinneapple Essence Starter for Environment/Climate Changing and Waste Recycling Topic of X Graders Madrasah Aliyah. Jurnal Pendidikan Dan Pembelajaran, 24(2), 79-84.

Gall, M. D., Gall, J. P., \& Borg, W. R. (2003). Educational Research: An Introduction, 7th Edition. New York: Pearson.

Hadi, S. (2017). Efektivitas Penggunaan Video Sebagai Media Pembelajaran Untuk Siswa Sekolah Dasar. Seminar Nasional Teknologi Pembelajaran Dan Pendidikan Dasar 2017, 96-102.

Haryadi, R., Vita, M., Utami, I. S., Ihsanudin, I., Setiani, Y., \& Suherman, A. (2019). Briquettes production as teaching aids physics for improving science process skills. Journal of Physics: Conference Series, 1157(3), 32006. IOP Publishing.

Jamaris, M. (2015). Orientasi Baru dalam Psikologi Pendidikan. Bogor: Penerbit Ghalia Indonesia.

John, A. N., Barasa, P. L., \& Omulando, C. (2017). The use of textbook illustrations in the teaching of reading comprehension: A study of secondary schools in Kathiani District-Kenya. International Journal of Research in Social Sciences, 7(8), 101121.

Khon, A. M. (2014). Hadis Tarbawi: Hadis-Hadis Pendidikan. Jakarta: Kencana Prenada Media Group.

Kurniawan, D., Wahyuningsih, T., \& Pangadongan, F. V. (2019). Pelatihan Kepada Guru SD untuk Mengajarkan Konsep Luas Bidang Datar dengan Menggunakan MEQIP (Mathematic Eduation Quality Improvement). International Journal of Community Service Learning, 3(2), 56-62.

Mashuri, S. (2019). Media Pembelajaran Matematika. Yogyakarta: Deepublish.

Megawati. (2017). Pengaruh Media Poster terhadap Hasil Belajar Kosakata Bahasa Inggris (Eksperimen di Sdit Amal Mulia Tapos Kota Depok). Getsempena English Education Journal, 4(2).

Menteri Pendidikan dan Kebudayaan RI. Peraturan Menteri Pendidikan dan Kebudayaan Republik Indonesia Nomor 22 Tahun 2016 Tentang Standar Proses Pendidikan Dasar dan Menengah. , Pub. L. No. Nomor 22 tahun 2016 (2016).

Menteri Pendidikan Nasional Republik Indonesia. Peraturan Menteri Pendidikan Nasional Republik Indonesia Nomor 24 Tahun 2007 Tentang Standar Sarana dan 
Prasarana Untuk Sekolah Dasar/Madrasah Ibtidaiyah (SD/MI), Sekolah Menengah Pertama/Madrasah Tsanawiyah (SMP/MTs), dan Sekolah Menengah Atas/Madrasah A. , (2007).

Moreira, I. X., Pereira, S., \& Gusmão, H. F. (2018). The Influence of Concrete Instructional Media on Learning Achievement. ISCE: Journal of Innovative Studies on Character and Education, 2(1), 104-114.

Muhammad Yaumi. (2018). Media dan Teknologi Pembelajaran. Jakarta: Prenada Media.

Munir, A. (2008). Tafsir Tarbawi: Mengungkap Pesan Al-Quran tentang Pendidikan. Yogyakarta: TERAS.

Nata, A. (2009). Tafsir Ayat-Ayat Pendidikan. Jakarta: PT. Raja Grafindo Persada.

Pemerintah Republik Indonesia. Undang-undang Republik Indonesia Nomor 20 Tahun 2003 tentang Sistem Pendidikan Nasional. , Pub. L. No. Nomor 20 Tahun 2003 (2003).

Pemerintah Republik Indonesia. Peraturan Pemerintah Republik Indonesia Nomor 19 Tahun 2005 Tentang Standar Nasional Pendidikan., Pub. L. No. 19 tahun 2005 (2005).

Pemerintah Republik Indonesia. Peraturan Menteri Pendidikan Nasional Nomor 16 Tahun 2007 Tentang Standar Kualifikasi Akademik Dan Kompetensi Guru. , (2007).

Prastowo, A. (2018). Sumber Belajar dan Pusat Sumber Belajar: Teori dan Aplikasinya di Sekolah/ Madrasah. Jakarta: Prenadamedia Group.

Pusat Bahasa. (2009). Tesaurus Alfabetis Bahasa Indonesia (1st ed.). Jakarta: Mizan Pustaka.

Rahmat, N. H. (2018). Educational Psychology: a Tool for Language Research. PEOPLE: International Journal of Social Sciences, 4(2), 655-668.

Rifai, M. H. (2017). Pemilihan Media Dalam Pembelajaran Geografi. Edudikara: Jurnal Pendidikan Dan Pembelajaran, 2(2), 125-136.

Rusman, Kurniawan, D., \& Riyana, C. (2012). Pembelajaran Berbasis Teknologi Informasi dan Komunikasi: Mengembangkan Profesionalitas Guru (1st ed.). Jakarta: Rajawali Pers.

Sahidin, L., Budiarto, M. T., \& Fuad, Y. (2019). Developing Vignettes to Assess Mathematical Knowledge for Teaching based Conceptual. International Journal of Instruction, 12(3), 551-564.

Sani, R. A. (2019). Inovasi Pembelajaran. Jakarta: Bumi Aksara.

Saputra, M., \& Kuswanto, H. (2019). The Effectiveness of Physics Mobile Learning (PML) with HomboBatu Theme to Improve the Ability of Diagram Representation and Critical Thinking of Senior High School Students. International Journal of Instruction, 12(2), 471-490.

Schunk, D. H. (2012). Learning theories: an educational perspective 6th ed. In Terjemahan Hamdiah \& Rahmat Fajar). Yogyakarta: Pustaka Pelajar.

Smaldino, S. E., Lowther, D. L., \& Russell, J. D. (2012). Instructional Technology \& Media for Learning: Teknologi Pembelajaran dan Media untuk Belajar (2nd ed.). Jakarta: Kencana Prenada Media Group.

Sukardi. (2003). Metodologi Penelitian Pendidikan: Komnpetensi dan Praktiknya. Jakarta: PT. Bumi Aksara.

Suryani, N., Setiawan, A., \& Putria, A. (2018). Media Pembelajaran Inovatif dan Pengembangannya. Bandung: PT. Remaja Rosdakarya, 5. 
Suyanto, M. (2005). MULTIMEDIA Alat Untuk Meningkatkan Keunggulan Bersaing. Yogyakarta: Andi.

Tim Lajnah Pentashihan Mushaf Al-Qur'an. (2019). Tafsir Maudhu'i (Tafsir Al-Qur'an Tematik); Komunikasi dan Informasi. Jakarta: PT. Lentera Ilmu Makrifat.

Wahidin, U., \& Syaefuddin, A. (2018). Media Pendidikan dalam Perspektif Pendidikan Islam. Edukasi Islami: Jurnal Pendidikan Islam, 7(01), 47-66.

Wicaksono, A. G., Irmade, O., \& Jumanto, J. (2017). Analisis Kebutuhan Pengembangan Media Komik Kontekstual Dalam Pembelajaran Sains SD. Jurnal Komunikasi Pendidikan, 1(2), 112.

Widodo, S. A. (2018). Selection of Learning Media Mathematics for Junior School Students. Turkish Online Journal of Educational Technology-TOJET, 17(1), 154160.

Yusuf, K. M. (2013). Tafsir Tarbawi: Pesan-pesan Al-Qur an tentang Pendidikan (A. Zirzis, ed.). Jakarta: Amzah. 